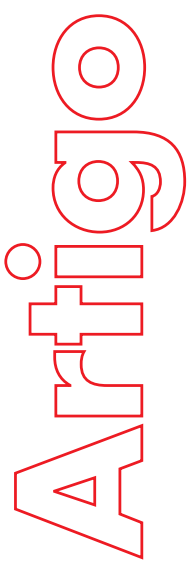

\section{Revista}

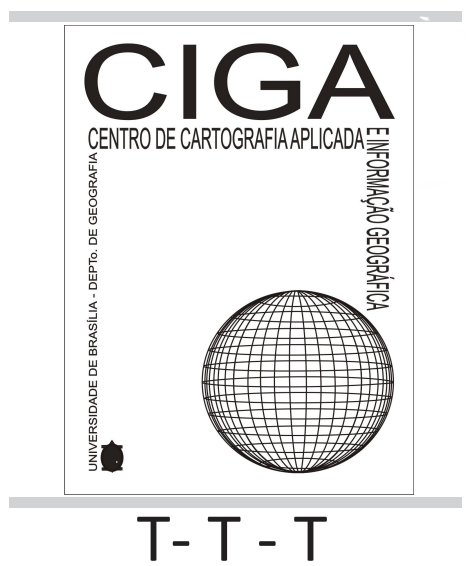

Revista Eletrônica: Tempo - Técnica - Território, V.10, N.2 (2019), 31-53 ISSN: 2177-4366

\section{PELO RETORNO À ÁFRICA: MEMÓRIAS SOBRE PAI ADAOO EM TERRITORIOS TRANSATLANTICOS (RECIFE, 1877-1936)}

\section{Bruno Maia Halley}

p. $31-53$

Como citar este artigo:

Halley, B, M.

PELO RETORNO À ÁFRICA: MEMÓRIAS SOBRE PAI ADÃO EM

TERRITÓRIOS TRANSATLÂNTICOS (RECIFE, 1877-1936) Revista

Eletrônica: Tempo - Técnica - Território, v.10, n.2 (2019),p.31-53

ISSN: 2177-4366.

Disponível em: http://periodicos.unb.br/index.php/ciga/

Este obra está licenciado com uma Licença Creative Commons Atribuição - Não Comercial 4.0 Internacional. 


\title{
PELO RETORNO À ÁFRICA: MEMÓRIAS SOBRE PAI ADÃO EM TERRITÓRIOS TRANSATLÂNTICOS (RECIFE, 1877-1936)
}

\author{
Bruno Maia Halley \\ Doutor em Geografia pela Universidade Federal Fluminense e Professor Substituto do \\ Departamento de Geografia da Universidade Federal do Rio Grande do Norte/Natal, \\ E-mail: bhalleype@,gmail.com
}

\begin{abstract}
RESUMO: Felipe Sabino da Costa, o Adão, nasceu em 1877, no engenho Itaguary, na Madalena, arredores do Recife, onde passou a mocidade. Filho de um escravo, casou com Maria da Hora Ananias e teve cinco filhos. Por razões religiosas circulou entre o Recife, Salvador e Maceió. Também foi à África para atualizar seus saberes. Passou anos em Lagos até desentender-se com sua parentela islâmica e rumar para a região central da África. De regresso ao Brasil, instalara-se em Água Fria, na Catimbolândia - maior concentração de xangôs entre as cidades do Recife e de Olinda, no começo do século XX, com mais de 35 casas de culto. Em 1919, assume a liderança do terreiro Ilê Axé Obá Ogunté, após a morte da ialorixá Tia Inês, exercendo sua trajetória de babalorixá até 1936 quando ocorre sua morte. As veredas e lugares do carismático Pai Adão (ou Adamaci - seu nome muçulmano), seus "retornos à África" por territórios transatlânticos no Nordeste do Brasil e em Lagos, suas redes de relações e tramas de poder são resgatadas no artigo ora descrito, apreendendo os marcos biográficos do afrorreligioso como memórias contextualizadas num período de profundas mudanças políticas, econômicas, sociais e culturais no Brasil.
\end{abstract}

Palavras-chaves: memórias; territórios transatlânticos; Pai Adão; Recife; África.

\section{FOR THE RETURN TO AFRICA: MEMORIES ABOUT PAI ADÃO IN TRANSATLANTIC TERRITORIES (RECIFE, 1877-1936)}

\begin{abstract}
Felipe Sabino da Costa, the Adão, was born in 1877, at the Itaguary mill, in Madalena, surroundings of the Recife, where he spent his youth. Son of a slave, he married Maria da Hora Ananias and had five children. For religious reasons has circulated between Recife, Salvador and Maceió. Also went to Africa to update his knowledge. Spent years in Lagos until he disagreed with his Islamic kindred and headed for the central region of Africa. On his return to Brazil, he had settled in Água Fria, in the Catimbolândia - the largest concentration of xangos between the cities of the Recife and of the Olinda at the beginning of the 20th century, with more than 35 houses of worship. In 1919, he took over the leadership of the Ilê Axé Obá Ogunté terreiro, after the death of ialorixá Tia Inês, pursuing her trajectory of babalorixá until 1936 when her death occurred. The paths and places of the charismatic Pai Adão (or Adamaci - his Muslim name), their "returns to Africa" by transatlantic territories in Northeast Brazil and Lagos, their networks of relationships, and plots of power are rescued in the article described here, as contextualised memories in a period of profound changes political, economic, social and cultural in Brazil.
\end{abstract}

Keywords: memories; transatlantic territories; Pai Adão; Recife; Africa.

\section{Notas iniciais: biografando Pai Adão}

Pai Adão nasceu em 1877, no engenho Itaguary, na Madalena, arredores do Recife, onde passou a mocidade. Era filho de um certo Sabino da Costa, o Alapinim, escravo e natural de Lagos, na Nigéria (FERNANDES, 1937). Foi batizado Felipe Sabino da Costa, em homenagem ao 
pai, mas era conhecido popularmente como Adão, corruptela abreviada do seu nome muçulmano Adamaci. Membro da Irmandade dos Martírios, casou na Igreja Católica, com Maria da Hora Ananias, com quem teve cinco filhos. Por razão de suas relações religiosas durante anos movimentara-se entre as cidades do Recife, Salvador e Maceió. Mas seu sonho era conhecer a terra dos seus maiores. Foi à África através de uma viagem familiar, para rever amigos e parentes (inclusive islâmicos), e atualizar seus saberes. Fez viagens em cargueiros e conseguiu realizar o seu desejo incontido. Adão passou anos em Lagos até desentender-se com sua parentela e rumar para a região central da África.

De regresso ao Brasil, instalara-se em Água Fria, nos arredores da Catimbolândia - maior concentração de terreiros de xangô entre as cidades do Recife e de Olinda, nas primeiras décadas do século XX, com cerca de 35 casas de culto (HALLEY, 2017). Em 1919, assume a liderança do terreiro Ilê Axé Obá Ogunté, após a morte da ialorixá Tia Inês, iniciando sua trajetória como maior babalorixá da capital pernambucana (Figura 01). Na Estrada Velha de Água Fria, recebia seus fiéis sentado numa cadeira de vime, todo de branco e fumando charutos. Era um grande místico, carismático e polêmico, contando com amizades influentes, como o sociólogo Gilberto Freyre. Morreu em 1936, aos 59 anos, cercado de homenagens.

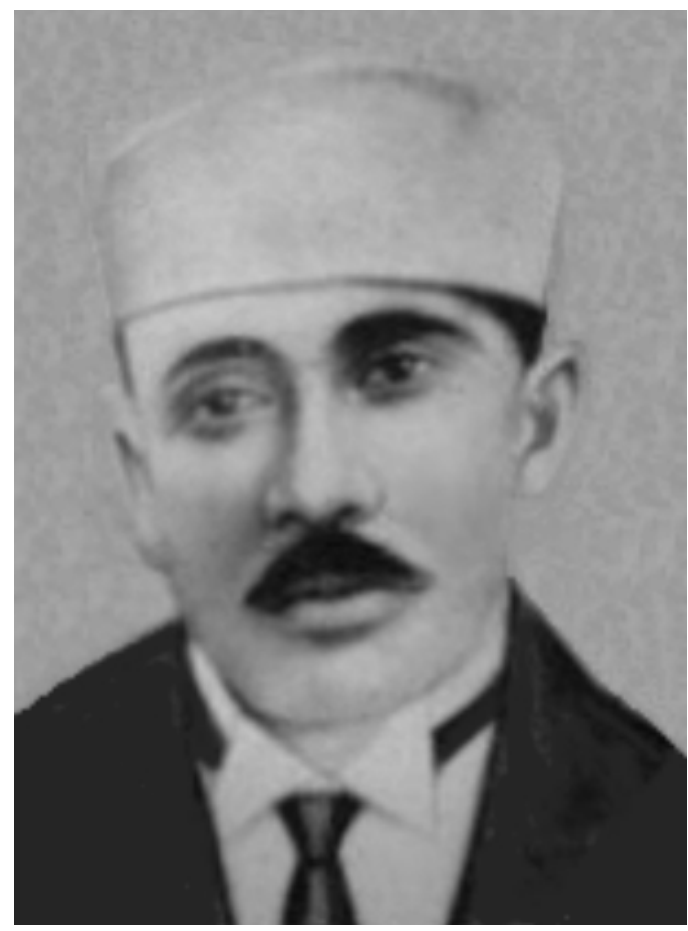

Figura 01: Pai Adão com gorro, bigode, paletó e gravata na sua fase adulta, s/data, já na condição de babalorixá. O desenho de autoria desconhecida encontra-se exposto na entrada do salão de toque do Sítio de Pai Adão, em Água Fria, na Zona Norte do Recife.

Fonte: Acervo do Terreiro Ilê Axé Obá Ogunté.

Os paradeiros de Adão, suas veredas, redes de relações e tramas de poder foram resgatados no trabalho ora descrito, compreendendo as memórias do líder religioso e seus territórios transatlânticos 
entre o Brasil e a África. Nesta revisitação territorial, contudo, não se procura "[...] discutir a memória individual, por definição subjetiva e única, mas a memória compartilhada, a memória solidária" (ABREU, 1998, p. 82) sobre Adão, que também configura-se parte das memórias dos lugares por onde ele passou e viveu. Com efeito, registra-se suas idas à Salvador e Maceió; sua viagem de "reafricanização" para Lagos; a saída e o retorno ao Sítio - seu território por excelência na Catimbolândia; e seu enterro no Cemitério de Santo Amaro, no Recife, sua derradeira morada, justamente num antigo espaço de quarentena do tráfico negreiro em Pernambuco. Ali foi seu último "retorno" à África

Os caminhos e os lugares descritos nesta biografia assentam-se em informações contidas em jornais; em estudos pioneiros sobre o xangô pernambucano; e em trabalhos acadêmicos calcados nas religiões afro recifenses. Afora essas fontes, também fez-se uso de passagens da obra de Gilberto Freyre sobre seu amigo Adão, e de diversas oralidades construídas sobre o líder religioso, sobretudo as reproduzidas por seus filhos de santo. Através deste levantamento, revelou-se controvérsias e pontos comuns nas oralidades e memórias institucionalizadas, conforme ensina Pollack (1992), procurando reconstituir coerentemente a memória sobre Adão numa periodização biográfica, delimitada entre os séculos XIX e XX.

Nesta retrospectiva, contextualizou-se a trajetória de Adão do nascimento (1877) ao seu óbito (1936), apreendendo-a como parte da memória coletiva de uma comunidade étnico-religiosa, preservada por gerações e gerações em discursos, práticas e construções simbólicas. Revisita-se essa jornada num período de profundas mudanças políticas, econômicas, sociais e culturais no Brasil, marcado, dentre outros eventos, pelo fim da escravidão (1888) e o início da República (1889). Neste contexto, o Recife assistiu transformações significativas, com a elite político-econômica idealizando uma cidade sã, moderna, católica e branca, distante das heranças coloniais africanas, tidas como "feias" e "atrasadas". Houve, assim, uma forte perseguição aos xangôs, inclusive com o uso do aparato policial, e, depois, com o controle científico-territorial de médicos-psiquiatras do então Serviço de Higiene Mental de Pernambuco - S.H.M., que também contava com o apoio de intelectuais regionalistas (como Gilberto Freyre), que se mostravam interessados em estudar a tradição dos povos afro-brasileiros na formação da identidade nacional.

Os contatos estabelecidos por Adão com estes indivíduos da ciência também foram revisitados, sobretudo quando da organização do $1^{\circ}$ Congresso Afro-Brasileiro, em 1934, que contou com o trabalho conjunto de chefes de terreiros, psiquiatras e intelectuais, com Adão participando da fase inicial de preparação do evento. Nesta trama de relações, o babalorixá fez uso de diversos meios para provar a "autenticidade cultural" do seu terreiro, procurando afastar a imagem de seu terreiro de outras casas de culto, tidas como de "baixo espiritismo", reduto de "charlatães" e de "doentes mentais", 
casas "impuras" que deturpavam a "tradição" dos centros afro-brasileiros, segundo o discurso do S.H.M. ${ }^{1}$

Em outros casos, contudo, Adão e seu povo recriaram táticas inventivas para fazer valer suas resistências frente aos indivíduos contrários à crença. Combinaram as táticas aos seus múltiplos saberes e práticas de caráter comunitário, imbuídas de outras matrizes de racionalidade, para além das ditas "científicas", que pela essência revelavam resistências construídas dentro de uma relação harmoniosa e mítica do homem com a natureza. Na Catimbolândia, as ações de Adão, como de outros afrorreligiosos, ocorriam dentro e fora dos terreiros, apreendidos como territórios "geossimbólicos" (BONNEMAISON, 2012), imersos por objetos sagrados do sincretismo religioso - habitados por santos católicos, divindades (orixás) e ancestrais africanos (eguns), e por construções profanas espaços de lazer e moradia dos filhos de santo. Eram territórios étnicos circunscritos por construções e objetos-rituais, onde tudo neles contidos, dotavam-se de simbolismos e identidades.

O terreiro de ontem e hoje, portanto, representa um território transatlântico por excelência, um espaço "transcultural" (ORTIZ, 1991) imbuído de influências culturais diversas, sobressaindo, contudo, as experiências de origem africana, com suas referências de identidade e pertencimento extrapolando os limites da casa de culto. À época de Adão, as territorialidades do povo de santo ganhavam os bairros, ruas e outros espaços públicos, situando-se tanto num campo eminentemente simbólico, como em ações efetivas, na construção e defesa material do espaço de identidade, mesmo quando ausentes do território. "Nesse sentido, a territorialidade se apresenta(va) como o esforço coletivo de grupo social para firmar a sua ocupação, para manter o seu ambiente e ter definido o seu território" (ANJOS, 2011, p. 16).

Em muitos casos, em face às ameaças, os xangôs tornavam-se "invisíveis", camuflando-se em centros kardecistas ou maracatus; também ocultavam seus orixás por trás dos santos católicos, ou quando das invasões policiais, os escondiam no iroko (árvore sagrada) ou nas casas de parceiros de fé; dependendo da situação, reagiam de modo inusitado, ou tratavam com agressividade os opositores da crença; durante a noite realizavam o "xangô rezado baixo"; ou ainda construíam suas estratégias nos espaços públicos, ritualizando árvores, beira de rios, os montes, tufos de matas, e ainda, as encruzilhadas suburbanas (HALLEY, 2017; GUERRA, 2010; COSTA, 2009; CAMPOS, 2001).

Os afrorreligiosos do Recife estavam imersos nestas territorialidades. Além destas, Adão preocupava-se também em aprender, repassar e preservar os saberes de cultos dos seus ancestrais, sempre retornando às tradições iorubá da terra-mater - a África. Ao mesmo tempo, contudo, exercitava um sincretismo afro-católico no Recife, em Salvador, Maceió, e até em Lagos, como

\footnotetext{
${ }^{1}$ A propósito do discurso do S.H.M. sobre os cultos afrorreligiosos, ver o artigos do Boletim de Higiene Mental e da revista Arquivos da Assistência a Psicopatas do serviço médico-psiquiatra de Pernambuco. A título de exemplo, vide o artigo O Espiritismo no Recife, que integra a edição do Boletim de Higiene Mental, de fevereiro de 1934.
} 
crença assimilada e como estratégia de maior aceitação social em face à perseguição étnico-religiosa da época. Foi neste universo místico, por entre territórios transatlânticos, que Pai Adão construiu parte de sua figura carismática como maior referência da tradição religiosa nagô do Recife.

\section{Nos "arredores-esconderijos": Tia Inês e Adão na Catimbolândia}

Se no Rio de Janeiro, os povos de santo estiveram situados na Pequena África, entre o século XIX e começo do XX, às margens da Baía de Guanabara, na zona portuária da Gamboa e Saúde (MOURA, 1995); e se em Salvador, os candomblés do povo nagô concentraram-se no Recôncavo Baiano, e em Cachoeira e em São Félix (NASCIMENTO, 2010); no Recife, por sua vez, os terreiros foram se fixando nas terras drenadas pelo rio Beberibe, nos arredores pobres situados na divisa com Olinda. Desprovida de uma grande reentrância natural, como a Guanabara ou a Baía de Todos os Santos, os xangôs da capital pernambucana refugiaram-se nas terras do Beberibe, historicamente um espaço de forte presença negra desde o período colonial (HALLEY, 2017).

Entre o fim do século XIX e início do XX, com a modernização e higienização ocorridas nos bairros-ilhas centrais do Recife, combinadas com o fim da Escravidão, com a escassez de moradias e com a intensificação da repressão contra os xangôs, as nações de culto de origem jêje-nagô, xanhá, savalu e calabar, procedentes de Angola, Congo e Costa da Mina, passaram a se refugiar nos arredores, saindo de espaços como São José, Boa Vista e Afogados e concentrando-se no vale do rio Beberibe. $^{2}$ Foram nos mocambos, sítios frutíferos, alagados, mangues e matas dos arredores do Beberibe que as famílias de santo se fixaram. Eram áreas pouco povoadas, menos fiscalizadas, verdadeiros “arredores-esconderijos” para os xangôs: Água Fria, Arruda, Fundão, Campo Grande, Encruzilhada, Mangabeira, entre outros (HALLEY, 2017).

Nestes arredores pobres conformou-se a Catimbolândia, cujos primeiros indícios de ocupação datam da segunda metade do século XIX, com a fundação do terreiro Ilê Axé Obá Ogunté de origem jêje-nagô, na Estrada Velha de Água Fria. A data de sua criação é imprecisa. Segundo a tradição oral, a construção da casa teve início há aproximadamente cento e cinquenta anos. ${ }^{3}$ Sua fundadora teria sido a ialorixá Inês Joaquina da Costa, a Ifatinuke, conhecida como “Tia Inês”, uma africana trazida para o Brasil pelo também africano João Otolú (PEREIRA, 1994). ${ }^{4}$

\footnotetext{
${ }^{2}$ Em sua maioria, essas linhagens de culto procederam de cativos oriundos de Angola/Congo. Outra menor parte adveio do atual Golfo do Benin (antiga Costa da Mina), abrangendo o leste de Gana, Togo, as cidades do Porto Novo e Uidá, no Benin, e parte ocidental da Nigéria (COSTA, 2013). As trocas culturais entre os povos destes territórios foram fundamentais para o complexo religioso dos xangôs no Recife.

${ }^{3}$ Mesmo sem informar as fontes, Jorge de Carvalho afirma o seguinte sobre a fundação do terreiro: "The sítio was founded around 1860 or 1870 by na African woman called Inês Joaquina da Costa...” (“O sítio foi fundado por volta de 1860/70 por uma mulher africana chamada Inês Joaquina da Costa...”) (CARVALHO, 1984, p. 80). Trata-se de uma versão da história que coincide com a tradição oral do Sítio de Pai Adão.

${ }^{4}$ Roger Bastide (1946, p. 1963) fornece uma informação semelhante sobre Inês: “O Xangô não se enraizou aqui com muita profundidade. Um único santuário tinha uma tradição verdadeira, o de Pai Adão. Fora fundado por uma antiga princesa da África trazida para o Brasil como escrava, e que por causa de sua origem recebera o nome de Baronesa....
} 
“Tia Inês” era uma negra de ganho até a conquista de sua alforria, em $1875 .{ }^{5}$ De acordo com uma versão da história, "Inês era filha de escravos e frequentava a casa de Eugênia, no Pátio do Terço, no bairro de São José, um dos mais antigos xangôs do Recife” (BRANDÃO, 1986, p. 178). ${ }^{6}$ Quando liberta, a sacerdotisa de Ifá, teria recebido de uns portugueses de Olinda a herança de um terreno próximo ao Chapéu do Sol, em Água Fria (BRANDÃO, 1986). A propriedade situava-se nas terras da Senhorinha Germana do Espírito Santo, cuja propriedade, o "Beberibe de Baixo", começara a ser loteada ainda em 1867. ${ }^{7}$ O loteamento devia-se à chegada da linha do trem Recife-Beberibe, inaugurada em 1871, cujo abrigo Chapéu do Sol serviu de estação (SETTE, 1938). Decerto, no bojo destes acontecimentos, a ialorixá adquiriu o sítio junto à portuguesa Germana, abrindo seu terreiro que passaria a ser um centro de atração para outros xangôs naqueles arredores do Recife e de Olinda, dando início a formação da Catimbolândia (Figura 02) (HALLEY, 2017).

Durante sua vida, "Tia Inês não teve filhos consanguíneos, porém adotou quatro: Maria Lori, Onorina, Antônio da Costa e Vicência" (PEREIRA, 1994, p. 48). Teria criado Vicência, pois vivera maritalmente com João Otolú, pai consanguíneo desta. Com a morte de João, Tia Inês registrou-a como filha. Nesta época, Adão, o ogebií, já residia no terreiro. Veio morar com a ialorixá, sendo filho de santo dela e uma espécie de assistente ou 'acipa', como assim de chama em Pernambuco. Após a morte de Inês, em 1919, o terreiro passou a ser liderado por Adão. Não se sabe exatamente porque ele herdou a casa de culto, tampouco o tipo de relacionamento do mesmo com Inês (BRANDÃO \& MOTA, 2002; PEREIRA, 1994).

Segundo Brandão (1986), a história desta relação é confusa, embaralhada ao menos em três oralidades. Walfrido José da Silva, o ogã mais antigo do Sítio, contara para historiadora, que Adão e Inês eram mais que bons amigos. Isso levou a escolha de Adão como sucessor, que também mostravase mais qualificado em razão dos ensinamentos em iorubá adquiridos quando de sua viagem à África, em 1906. Outra versão diz que Adão a trouxe consigo da Nigéria, alçando voo sozinha, ao ponto de fundar o terreiro, mas sem romper por completo seu relacionamento com o amigo, a quem legou a casa. Em outra versão, Adão teria rompido a linha sucessória do Sítio sem a autorização de Inês, usurpando a posição de Joana Batista, filha e legítima sucessora da ialorixá. O babalorixá alegava ser uma ordem dos orixás (BRANDÃO, 1986).

\footnotetext{
${ }^{5}$ ARQUIVOS da Assistência a Psicopatas de Pernambuco, 1935, p. 88.

${ }^{6}$ Outra versão menos provável fora apresentada por Carvalho: "She bought the sítio land and is said to have come from wst the purpose of establishing the African religius tradition in the city...". "Ela comprou a terra do sítio e é conhecida como tendo vindo da África Ocidental com vários objetos rituais, com o objetivo de estabelecer a tradição africana na cidade" (CARVALHO, 1984, p. 80). Dificilmente a ialorixá Inês sairia da África à procura de uma terra ainda baseada na escravidão, entre os anos de 1860-70. Dada as mudanças ocorridas no Recife, ao longo do século XIX e começo do XX, mais provável é a hipótese relatada por Maria do Carmo Brandão (1986), a qual Inês deslocara-se do bairro central de São José para os arredores da cidade, para a Água Fria, justamente no período de loteamento daquelas terras.

${ }^{7}$ Conforme consta na "Petição da Senhorinha Germana do Espírito Santo à Câmara Municipal de Olinda", s/data (apud ARAÚJO, 2007).
} 


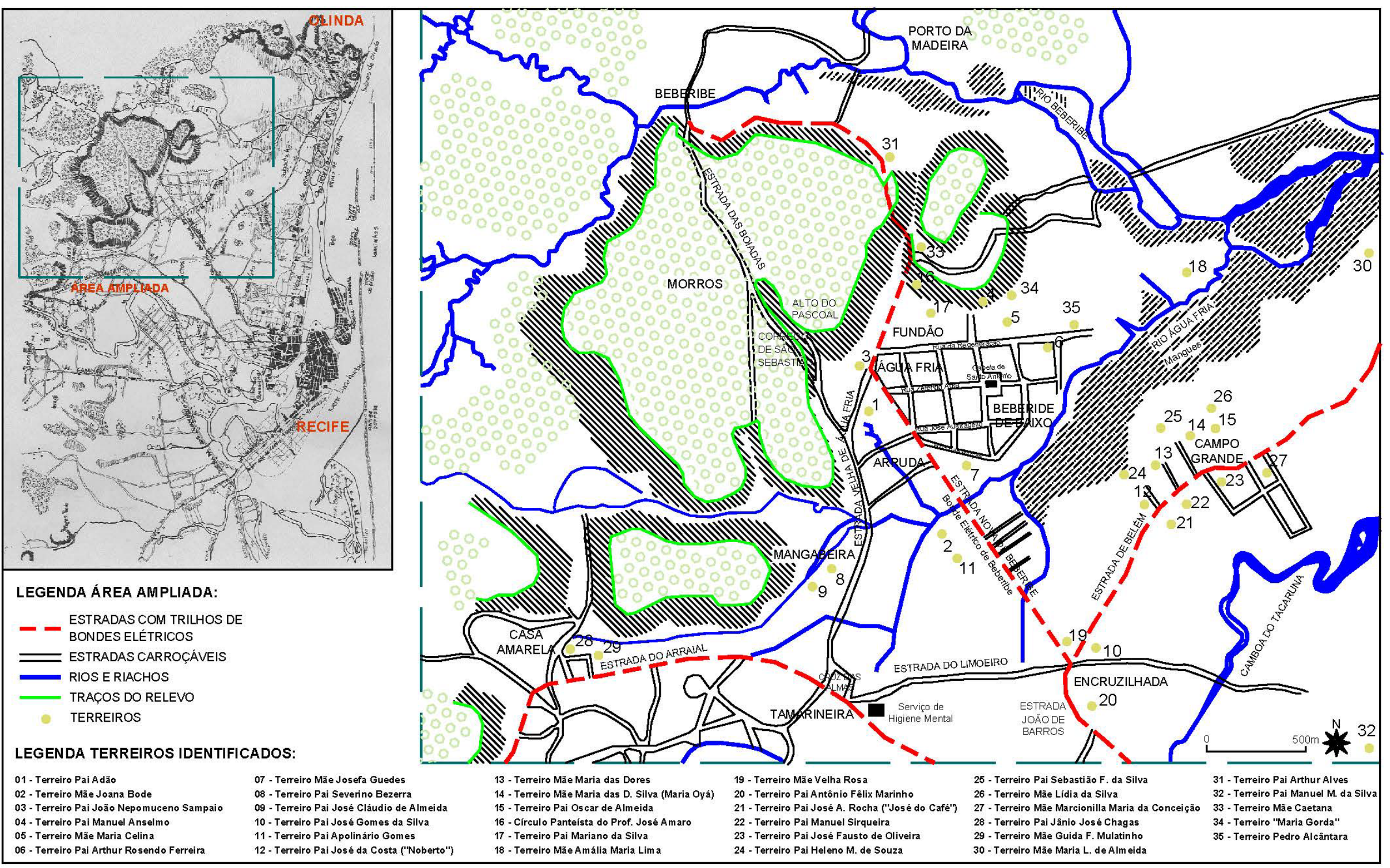

Figura 02: Pormenor dos xangôs nos arrabaldes do rio Beberibe - a Catimbolândia, no decênio de 1930, entre as cidades do Recife e de Olinda. Observe-se na imagem a localização do Terreiro de Pai Adão (número 01). Desenho: Bruno Maia Halley (2017). Fonte adaptada: Planta da Cidade do Recife e seus Arredores - 1876, com informações adicionais da Planta do Departamento de Saúde e Assistência Médica do Recife - 1924 e da pesquisa direta do autor em fontes diversas. 
Malgrado as distintas versões da história, sabe-se ao certo que João Querino entrou numa celeuma com Adão, desgostoso de vê-lo sucessor, ao invés de Joana Batista, conhecida popularmente como Joana "Bode" ou "Joaninha". Como era de se esperar, a substituição da continuidade feminina pelo carisma masculino e não consanguíneo, enfrentaria muitas objeções, levando Adão a entregar a chefia do terreiro à Querino, e, depois, a afastar-se do Sítio por alguns anos, indo morar na Rua Bom Conselho, no arrabalde do Arruda (BRANDÃO \& MOTTA, 2002).

No entanto, após a morte de Querino, Adão reassumiu definitivamente a liderança da casa, destacando-se entre os líderes de santo, não somente pelo seu tradicionalismo e conhecimento sobre o culto dos orixás, mas por sua personalidade carismática, no sentido weberiano, com espírito de liderança incomum, havendo praticamente uma devoção à sua figura. ${ }^{8} \mathrm{O}$ início de sua ascensão religiosa ocorre quando de sua ida à África, sob domínio do imperialismo europeu, em busca de ensinamentos na terra-mater dos seus ancestrais. Mesmo imerso nas trocas culturais do sistema colonial, o contato estabelecido com a parentela africana de origem islâmica lhe proporcionou saberes exclusivos sobre o culto iorubá, projetando-o como babalorixá quando de seu regresso ao Recife.

\section{Nas rotas de uma "reafricanização": Adão e sua viagem à Lagos.}

Filho de um escravo chamado Sabino da Costa, Adão tinha o sonho de conhecer a terra dos seus maiores. Em viagem transatlântica rumou até o território de seus ancestrais africanos, a Nigéria, então sob domínio colonial inglês. Foi à cidade de Lagos, em 1906, através de uma viagem familiar organizada por Marcolina da Silva Marques, a Dudu Obaytó. Dudu nasceu em 1879, e como Adão, era filha de santo do terreiro de Inês, sendo filha e neta de escravos de ganho alforriados. De sua parentela, composta por africanos e crioulos da Rua Imperial (bairro de São José), herdou o culto aos ancestrais e divindades africanos, além da crença ao islamismo. Um momento particular na trajetória de Dudu fora a viagem de retorno à África junto com sua família para rever amigos e parentes, conhecer lugares e atualizar seus saberes de culto. Nesta viagem foram Rita, Cassiano, Abianê, Cariba, Eva e Adamaci - o nome muçulmano de Pai Adão. ${ }^{9}$

O real motivo da viagem de Dudu foi a doença do tio Cassiano. Tia Rita pediu ao orixá Iansã que permitisse que o marido morresse na África. No caso de Adão, o motivo maior centrava-se no processo de "reafricanização", na aquisição ou reconstrução de tradições nagô, trazendo à luz mitos

\footnotetext{
${ }^{8}$ Sobre a personalidade carismática de Pai Adão, ver a biografia escrita por Gonçalves Fernandes (1937) em Xangôs do Nordeste; o artigo de Maria do Carmo Brandão e Roberto Motta (2002); a monografia de Anilson J. Bezerra Lins (1992); e a dissertação de Zuleica Pereira (1994). Afora estes, há também passagens na obra de Gilberto Freyre sobre Pai Adão, nos livros Sobrados e mucambos, de 1936 (2013), Guia prático, histórico e sentimental da cidade do Recife, de 1934 (1968), e Pessoas, coisas \& animais, de 1979, além de uma crônica no Diário de Pernambuco em homenagem à Adão quando do seu falecimento: PAE ADÃO. Gilberto Freyre. Diário de Pernambuco. Recife, 28 de abril de 1936 , p. 03.

${ }^{9}$ A historiadora Valéria Gomes Costa (2013) teve acesso ao manuscrito da entrevista realizada pelo antropólogo René Ribeiro junto à filha de santo Marcolina da Silva Marques, em 1954. Nesta entrevista, a Dudu Obaytó relatou a sua viagem parental rumo à África, e, assim, a ida de Pai Adão a Lagos. Vide em: Anotações de René Ribeiro, 1954 [Dudu].
} 
e histórias de fundação de uma cultura africana reinventada. Nesta "(re)invenção de tradições" (HOBSBAWN \& RANGER, 2002), Dudu e Adão, afora os outros parentes, contribuíram para a reconstrução do saber e divulgação do Xangô, alcançando maior visibilidade e aceitação junto aos médicos-psiquiatras do S.H.M. e intelectuais regionalistas, então interessados em controlar o funcionamento dos terreiros e em discutir o papel do negro na formação do povo brasileiro, respectivamente. À época, as buscas de "retorno à origem" validavam os xangôs como "autênticos" redutos de manifestações afro-brasileiros (SOIHET, 1998).

O próprio Gilberto Freyre enaltecia a iniciativa do mulato Adão em se "reafricanizar" dado ao grau de mestiçagem e a perda de originalidade dos costumes africanos no Recife. O sociólogo ressaltou que os líderes religiosos negros de sua época já eram mulatos. "Mulatos, alguns deles já muito desafricanizados nos seus estilos de vida, mas que se reafricanizaram indo estudar na África. Tal o caso de Pai Adão, do Recife, que se fez pai de santo em Lagos; que falava africano com a mesma facilidade com que falava português" (FREYRE, 2003, p. 500). ${ }^{10}$

Na sua travessia transatlântica, transétnica e transnacional, Adão passou por alguns portos até alcançar à pátria de seus maiores: “[...] tomou um cargueiro para Lisboa, dali um outro para Las Palmas e num barco inglez alcançou Lagos (1906)" (FERNANDES, 1937, p. 56-57). Nesta cidade passou algum tempo, até desentender-se com o filho do tio Cassiano, que já morava em Lagos, levando-o a deixar a casa que o acolhera e rumar para a região central da África. ${ }^{11}$ Durante quatro anos, "o continente do outro lado do mar lhe ensinou o que a sua intuição vislumbrava. Dominava-o inteiramente o culto dos seus pais" (FERNANDES, 1937, p. 154) e na língua iorubá, conforme destacou Freyre (1968).

A vontade de falar a língua da África, diferente da língua do colonizador, teve início ainda com seu pai, que familiarizou o filho com a religião (FERNANDES, 1937). Isso permitiu a Adão aperfeiçoasse no idioma iorubá e na liturgia do culto, mesmo diante das mudanças advindas das redes de fluxo e refluxo da escravidão e pós-abolição vivenciadas pelos africanos e seus descendentes nas américas. Com efeito, ao testemunhar sua viagem ao médico do S.H.M. Gonçalves Fernandes, Adão mencionou as transformações então em curso no xangô, decorrentes dos intercâmbios no mundo Atlântico, em especial dos libertos retornados à África: "Referiu-me mesmo que em Lagos, mercê da volta de muitos antigos escravos, outros mesmo libertos já de nascença, o culto yorubano se faz assim mesclado em muitos terreiros" (FERNANDES, 1937, p. 56-57).

\footnotetext{
${ }^{10}$ Malgrado a veracidade de sua viagem, também outro babalorixá situado na Catimbolândia, Artur Rosendo, patriarca da nação Xambá, afirmara ter visitado à África. Segundo René Ribeiro (1949), Rosendo viajara para Dakar, no Senegal, convivendo quatro anos com o povo Soba, da Costa da África. Aprendeu o idioma e os ritos religiosos de seus ancestrais, sobretudo com um feiticeiro, vendedor de panelas no Mercado de Dakar, chamado "Tio Antônio". Não se sabe ao certo o ano da viagem, pois Rosendo mostrava-se contraditório, até mesmo quando trocava palavras em iorubá com outros pais de santo.

${ }^{11}$ Anotações de René Ribeiro, 1954 [Dudu].
} 
Devido à intensa troca cultural promovida pelo sistema colonial, os rituais africanos já se revelavam imersos num processo de "transculturação" (ORTIZ, 1991), em especial nas zonas de maior troca identitária, nos territórios transatlânticos litorâneos. Ciente deste contexto, quando do retorno ao Recife, Adão engajou-se na reconstrução de uma tradição nagô na cidade, junto com seus parentes e com outros arranjos familiares e religiosos de descendentes africanos (COSTA, 2013). A procura por essa reinvenção iorubá fez de Adão o “maior babalorixá que já teve o Recife” (FREYRE, 2003, p. 103), não obstante suas ligações com comunidades católicas e islâmicas.

"Para os africanos e crioulos, pertencer a mais de uma comunidade religiosa era algo relevante para garantir seus arranjos políticos e sociais”, sublinha Costa (2013, p. 222). Sabedor disso, Adão circulava por outros grupos e espaços, fazendo valer seus propósitos e conhecimentos. No Recife, procurava legitimar seus saberes como iguais na diferença, mesmo que tidos como "inferiores" e/ou “folclóricos" pelos homens da razão científica, em particular médicos-psiquiatras do S.H.M. e intelectuais regionalistas. Nas tramas de poder tecidas com esses indivíduos, afora com outras lideranças religiosas, Adão buscava ressaltar sua ortodoxia nas coisas do culto, valendo-se muitas vezes de seu carisma como uma "arte de convencimento", ou mesmo de certa arrogância, quando se tratava da defesa direta de sua religião, sobretudo no seu "território-santuário" (BONNEMAISON, 2012), o terreiro de Água Fria.

\section{O regresso ao Brasil: o babalorixá Adão e suas tramas de poder.}

Quando de sua volta ao Brasil, Adão transitou entre o Recife, Maceió e Salvador (Figura 03), movimentando-se entre as capitais em razão de suas relações religiosas (COSTA, 2008). Segundo Fernandes (1937), chegou a residir em Maceió e também em Salvador. Na capital alagoana, muito provavelmente morou em algum bairro do reduto negro da cidade - Jaraguá, Trapiche da Barra ou Farol. ${ }^{12}$ Já em Salvador, acredita-se que ele tenha residido, durante algum tempo, próximo ao amigo e famoso babalorixá, o Martiniano Eliseu do Bonfim, com quem compartilhava saberes iorubas no Caminho Novo do Tabuão, no Pelourinho. No Recife, conforme já observado, assumiu a chefia do terreiro de Tia Inês, após a morte da ialorixá em 1919. Tempo depois, contudo, deixou a casa sob liderança de João Querino, sucessor legítimo de Inês, passando a residir nas redondezas, na Rua Bom Conselho, no Arruda (PEREIRA, 1994). Após a morte de Querino retomou a chefia do "Sítio", onde permaneceu até sua morte em 1936.

\footnotetext{
12 Outro famoso pai de santo do Recife, o babalorixá Arthur Rosendo, da nação Xambá, também tinha ligação com Maceió. Iniciado pelo Mestre Inácio, do bairro do Jaraguá, Rosendo tornou-se babalorixá, saindo de Maceió rumo ao Recife em razão do violento evento político-policial O Quebra ocorrido contra os terreiros da capital alagoana a partir de 1912. No Recife, fundou seu terreiro em Água Fria, em 1923, aglutinando e iniciando vários filhos de santo, inclusive Lídia Alves (a Lídia de Oxalá) e Maria das Dores da Silva (a Maria Oyá), futura matriarca do Xambá (GUERRA, 2010).
} 
Além de babalorixá, Adão também integrava a Irmandade dos Martírios, no Recife, casando-se na Igreja Católica com Maria da Hora Ananias, com quem teve cinco filhos (BRANDÃO \& MOTTA, 2002). A cada um ensinou um ofício, não queria vê-los nas coisas de santo, temia pela repressão. Seus filhos foram Sigismundo (pedreiro), José Romão (carpinteiro), Guilherme (alfaiate), Malaquias (marmorista) e Maria do Bonfim (costureira). Tem-se notícia de um outro filho mais velho, fruto de outro relacionamento, conforme assegura a historiadora Zuleica Pereira (1994).

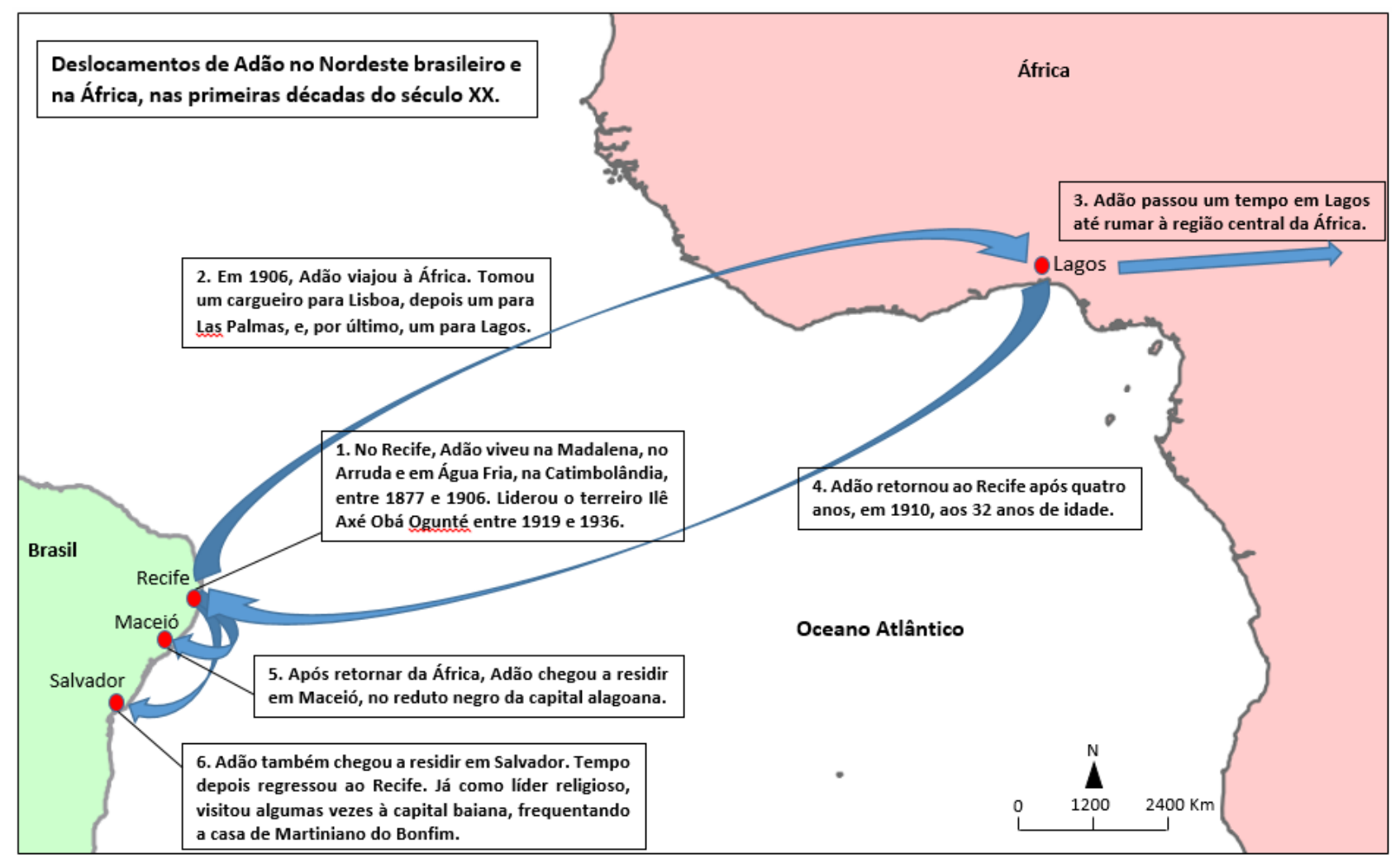

Figura 03: Cartografia dos deslocamentos de Pai Adão no Nordeste brasileiro e no continente africano, nas primeiras décadas do século XX. Desenho: Bruno Maia Halley.

Fonte adaptada: IBGE Mapas/continente (2008). In: http://www.mapas.ibge.gov.br Acesso: fevereiro de 2020.

Carismático como homem de confiança e líder aceito, Adão contava com inúmeras amizades, inclusive com intelectuais, como Gilberto Freyre: “[...] na sua casa de Água Fria muitas vezes almocei, jantei e ceei com o velho babalorixá", registrou o sociólogo pernambucano (FREYRE, 1936, p. 3). Costumeiramente, com o ar patriarcal, o pai de santo sentava-se na sua velha poltrona de jacarandá, trajando costume de brim engomado e gorro branco, com os molequinhos trepados em suas pernas de avô, e as noras e afilhadas servindo a mesa. Abençoava e aconselhava seu povo, julgando-se um grande sacerdote, figura quase sagrada, não aceitando se nivelar aos demais, os quais criticava pelas "impurezas" dos segredos do culto (FERNANDES, 1937; FREYRE, 1936).

Em 1934, quando se organizava o $1^{\circ}$ Congresso Afro-Brasileiro, reuniram-se no Hospital de Alienados de Pernambuco, próximo ao Sítio de Pai Adão, vários pais e mães de santo, psiquiatras e intelectuais regionalistas. "Foi uma reunião pitoresca, mas agitadíssima. Quase brilha punhal", no 
dizer de Freyre (1936). A ideia do Congresso pareceu magnífica para Adão, com foco nos problemas dos descendentes de africanos no Brasil, sua religião, história, condições de vida, saúde e arte. Segundo o sociólogo: "Foi um dos maiores entusiastas do Congresso. Posso mesmo dizer que foi em Pae Adão que encontrei o melhor inspirador para a direção que tomou afinal o congresso - único no gênero. Mais de uma vez ele me procurou em casa para tratar do assumpto" (FREYRE, 1936, p. 3).

Contudo, o ortodoxo Adão exigia apenas sua participação e do amigo Martiniano do Bonfim na organização do evento. Segundo o pai de santo de Água Fria, eles seriam os únicos babalorixás que entendiam verdadeiramente dos mistérios do Xangô, com suas formações religiosas realizadas na própria África. Negava a qualidade de outros líderes religiosos, considerando-os falsos profetas (FREYRE, 1936). ${ }^{13}$ Como Pai Adão, Martiniano também visitou à África, em missão religiosa na Rua Tòkúmbó, no Brazilian Quarter, em Lagos, entre 1875 e 1886 (PIERSON, 1942). No Brasil, visitou algumas vezes Pernambuco para realização de cerimônias então desconhecidas pelos religiosos locais. Nas vindas de Martiniano ao Recife e idas de Adão à Salvador, laços de amizade foram construídos entre os pais de santo, ao ponto do pernambucano homenagear o baiano com uma toada especial em iorubá (LOPES, 2004). Em nome da amizade e ortodoxia, "medonho barulho" foi provocado por Adão para tomar parte do Congresso (FREYRE, 1936). Acabou não participando. ${ }^{14}$ "Entre os diversos pais de terreiro do Recife foi a única excepção" (FERNANDES, 1937, p. 57).

Os traços da personalidade de Adão, seu gênio forte, arrogância e carisma, incomodavam os médicos do Serviço de Higiene Mental de Pernambuco, não somente no que concerne à organização do Congresso, mas sobretudo quando da visita dos psiquiatras à sua casa de culto. Segundo o médico Gonçalves Fernandes (1937, p. 57): "Seu porte é o de um grande chefe, arrogante, e trata aos médicos do S. H. M. de igual para igual. Deixa, porem, ás vezes, transparecer a sua gentileza em cumprimentos assim: "Só sinto alegria e só o dia é belo quando vejo você, etc.". Decerto, a gentileza de Adão consistia numa tática política com àqueles que tentavam controlar os xangôs, responsáveis em liberar o funcionamento ou não das casas, em classificar os centros como "puros", em africanidade, ou

\footnotetext{
${ }^{13}$ Segundo Maria do Carmo Brandão e Roberto Motta (2002, p. 53), a "incompetência" de outros pais e mães de santo não existia na realidade. Ao lado de Adão, “[...] bom número de outros babalorixás que, estritamente do ponto de vista da competência ritual e mitológica, não lhe eram inferiores e que até talvez o superassem quanto à pureza e correção das genealogias rituais. Lembrem-se os nomes de Anselmo, Artur Rosendo, Apolinário Gomes da Mota, Neri, sem contar com Manuel Mariano, que foi o grande informante de René Ribeiro". Todos estes tinham seus terreiros nos arredores do rio Beberibe - a Catimbolândia (HALLEY, 2017).

${ }^{14}$ Sobre a não participação do amigo Adão no $1^{\circ}$ Congresso Afro-Brasileiro, escreveu Freyre (1936, p. 3): "Sua exigência para tomar parte no Congresso é que era tremenda: só ele e Martiniano. Impossível transigir neste ponto com o bom amigo de Água Fria. Mas não houve zanga nenhuma entre nós. Nem podia haver. Logo ás suas primeiras intransigências em me lembrara de que outros Paes Adão, louros e chefes de seitas mais ilustres que a sua, tinham se recusado a comparecer ao Congresso de Religiões [...] em Chicago [...] Nossa amizade continuou como dantes". No caso de Martiniano do Bonfim, o babalorixá presidiu a organização do $2^{\circ}$ Congresso Afro-Brasileiro, realizado em Salvador, em 1937. De acordo com Gonçalves de Mello (1988, s/p), na apresentação dos Anais do $1^{\circ}$ Congresso: "Pai Adão, [...], embora tivesse comparecido a uma daquela preparatórias, recusou-se a participar do Congresso, pois não considerava os outros babalorixás seus iguais, pois que sua formação fora realizada na própria África, o que não acontecia com os demais".
} 
"impuros", repletos de "loucos" em frequente estado de "possessão". Freyre destacou a "diplomacia" de Adão frente a esses casos: "Elle se aproximava dos assumptos mais delicados com as cautelas de um gato em dia de chuva: evitando o molhado pisando no secco. Mas [...] sabia ser homem de palavra dura e franca (FREYRE, 1936, p. 3).

Um caso ocorrido em 1935 exemplifica bem essa personalidade de Adão. Em meio as disputas entre os terreiros da Catimbolândia, houve um imbróglio envolvendo o número anual de toques nos xangôs, então regulamentados pela Secretaria de Segurança Pública de Pernambuco - SSPPE. Malgrado a opinião de outros líderes, um calendário foi fixado com 18 toques pelo Pai Manuel Anselmo, com aprovação do S.H.M. Prestigiado por sua ortodoxia, Adão recebeu negativamente a distribuição das "festas", acusando Anselmo de praticar uma padronização às datas dos cultos (FERNANDES, 1937). Pai Oscar Almeida também discordara. Adão logo formulou protesto junto ao S.H.M., e Oscar narrou o imbróglio ao Diário de Pernambuco. ${ }^{15}$ Oscar chamou atenção para a falta de solidariedade de Anselmo em não consultar os outros babalorixás na redução dos "toques", como o pai Rosendo e o próprio Oscar. Reclamou da insuficiência no número de toques, inclusive para as datas mais simbólicas. Anselmo, por sua vez, respondeu ao Diário, realçando ser a "medida boa” para evitar "abusos" cometidos após as licenças liberadas pelo S.H.M., evitando, assim, a ação policial contra aos xangôs. ${ }^{16}$ Anselmo não queria associar sua casa ao "baixo espiritismo", procurando agradar o S.H.M.. Adão concordava em se "coibir abusos [...], mas dar voto lá no seu terreiro era que não podia ser. Lembrou que se fixasse em 18 o numero máximo de toques anuais, ficando quem quisesse com o direito de reuni-los quando fosse a vez. E assim se entenderam" (FERNANDES, 1937, p. 37).

Na Catimbolândia, a relação dos pais e mães de santo envolvia rivalidades dentro de uma espécie de "hierarquização sacerdotal", com algumas lideranças mais prestigiadas do que outras, engendrando uma maior ou menor aceitação social, inclusive frente à polícia, ao S.H.M. e à intelectuais. O próprios médicos do S.H.M. realizavam esta distinção, como Pedro Cavalcanti (1935) e Gonçalves Fernandes (1937), que classificaram os "bons terreiros" e os “catimbós” tidos como "sem competência". Adão tinha um maior reconhecimento pelos psiquiatras e intelectuais, o que gerava intrigas frente aos outros sacerdotes. Mesmo com as rixas, todos o tinham como grande babalorixá:

\footnotetext{
15 “À noite a nossa reportagem ouviu um dos "Babalorixás” do Recife - Oscar de Almeida. É o "Babalorixá" do Centro Africano Santo Sebastião, de culto nagô. Oscar estava acompanhado de José Tavares, "pai pequeno" do seu terreiro. [...] Eu protesto contra a medida [...] Por isso não posso me submeter á medida da polícia. [...] Não fui ouvido a respeito. Temos no terreiro 28 toques por ano e como vamos ficar reduzidos a 18? [...] nossas datas principais foram esquecidas. [...] Se a medida foi feita de acordo com Anselmo, como me disse Dr. Ulysses, ele não consultou os outros babalorixás. Eu acho que ele não ouviu também o babalorixá Rosendo. Se fomos nós três que fizemos o Congresso Afro - Brasileiro, essas medidas que nos interessam deviam ser consultadas a nós. E não fazer assim". In: VAI SER RESTRINGIDA A LICENÇA PARA OS TOQUES NOS XANGÔS A POLÍCIA BAIXARÁ UMA PORTARIA A RESPEITO. Diário de Pernambuco, Recife, 23 de julho. 1935.

${ }^{16}$ Idem: Diário de Pernambuco, Recife, 23 de julho. 1935.
} 
“e si em voz baixa falam mal [...], não é sem grande respeito com que o cumprimentam”, sublinhou Fernandes (1937, p. 56).

A posição mais firme de Adão ocorria quando havia alguma ameaça ao seu xangô. O "sítio" em si constituía um "território geossimbólico" (BONNEMAISON, 2012), onde tudo nele contido possuía uma identidade para o povo de santo - água, terra, árvores, construções e objetos-rituais. A interferência externa sobre seu terreiro engendrava em Adão, como em outros líderes de culto, a recriação de inúmeras estratégias de resistência. As bases dessas táticas eram eminentemente territoriais, tanto num campo simbólico-imaterial, como em ações concretas-materiais. Os terreiros, portanto, eram defendidos e/ou mantidos como espaços de identidades pelos adeptos dos xangôs, mesmo quando ausentes destes, ou quando da não existência material dos mesmos, o que recorda, assim, a noção de território em Haesbaert (2007).

Com efeito, frente aos opositores da crença, os xangôs camuflavam-se em centros kardecistas ou em maracatus, ambos mais aceitos socialmente. ${ }^{17}$ Dentro de uma enorme criatividade, também ocultavam seus orixás por trás dos santos católicos, ou quando das invasões policiais os escondiam no iroko (árvore sagrada) ou nas casas de amigos parceiros de fé - vide o caso de Joana Baptista mais adiante. Dependendo da situação reagiam de maneira inusitada - fingiam uma possessão ${ }^{18}$, ou, em outros casos, tratavam com agressividade os contrários à crença. ${ }^{19}$ Também deslocavam as sedes dos seus terreiros pelas ruas dos arredores do Beberibe. E, pela madrugada, realizavam o "xangô rezado baixo", com o toque quase silenciado dos tambores e os cânticos sussurrados ${ }^{20}$, com a Catimbolândia mantendo-se acordada enquanto adormecia a chamada Veneza Americana - formada pela elite político-econômica branca, cristã e europeia da capital pernambucana (HALLEY, 2017).

Os povos de santo buscavam o direito à diferença, recriavam estratégias territoriais frente uma luta contínua de transgredir um padrão de poder colonial, no caso, a repressora Veneza Americana. Afastados da possibilidade de se inscrever como protagonistas de direitos plenos, os afrorreligiosos tramavam as estratégias supracitadas, combinando-as aos saberes e práticas de caráter coletivo, que

\footnotetext{
${ }^{17}$ A esse respeito, anunciava a Folha da Manhã: "Muitos macumbeiros, cartomantes, disfarçados de espíritas tentam se instalar no Recife. A Delegacia e Capturas não os deixou em paz". In: A "MACUMBA" A SERVIÇO DO FUTEBOL. Folha da Manhã, Recife, 31 de julho. 1944, p. 4. Edição Matutina.

${ }^{18}$ Em 21 de março de 1938, a Folha da Manhã estampava a prisão de um babalorixá pela Delegacia de Investigações e Capturas. Quando preso, pai Antônio Pereira da Silva forjou "incorporar" uma "entidade" na tentativa de amedrontar os policiais e executar sua fuga. In: UM ESPÍRITO RUIM NO CORPO DO CATIMBOZEIRO PEREIRA. Folha da Manhã, Recife. 21 mar. 1938. p. 1. Edição das 16 horas.

${ }^{19}$ Segundo com o ativista negro Vicente Lima (1937), a "Baiana do Pina", incomodada com a presença dos técnicos do S.H.M. em seu terreiro, arrebatou-lhes os croquis quando os mesmos anotavam informações sobre o seu xangô.

${ }^{20}$ Vide matéria do Diário de Pernambuco a respeito: [...] essa campanha recrudesceu depois que a delegacia se certificou de que os infractores, principalmente os adeptos da seita africana, se mostravam dispostos a burlar as determinações contidas na circular do Secretário de Segurança, prohibindo seu funcionamento. Verificou a polícia que os xangôs, depois da referida prohibição, passaram a funcionar em sedes diferentes e a altas horas da noite, sem o característico toque dos tambores [...]. In: FECHADOS PELA POLÍCIA VÁRIOS XANGÔS. Diário de Pernambuco, Recife, 13 de fev. 1938 , p. 7 .
} 
pela essência revelavam-se resistências historicamente construídas no bojo da relação homemnatureza, da "[...] relação do homem com sua própria natureza humana, [...] e com a natureza-quelhe-é-exterior", como diz Porto-Gonçalves (2006, p. 400).

Comungando com matrizes de racionalidade não-ocidentais, com outras formas de sentir, pensar e agir, os adeptos dos xangôs realizavam seus rituais nos espaços públicos, em especial na geografia do rio Beberibe, junto às árvores sagradas - iroko, gameleiras e baobás, aos mangues e alagados, à beira de rios e córregos, nos tufos de mata, nos montes, e ainda, nas encruzilhadas suburbanas, como na famosa Cruz das Almas das Moças, antigo local de despachos próximo ao Sítio de Pai Adão (HALLEY, 2017). O próprio Adão fazia uso destas territorialidades, dentro e fora do seu terreiro, expondo culturalmente suas práticas, suas oferendas rituais incorporadas e inscritas no/pelo habitus, sempre em referência à terra de seus antepassados, à África.

\section{Notas finais: o último "retorno" à África}

"Toda cultura que convive com a natureza e não contra a natureza tem a morte sempre ritualizada, já que ela é o limite do homem", sublinha Porto-Gonçalves (2006, p. 410). Quando Pai Adão morreu, em 26 de março de 1936, houve um grande ritual dentro do sincretismo afro-católico da época. ${ }^{21}$ "Seu enterro foi um acontecimento. Verdadeira multidão", relatou Freyre (1968, p. 102), provocando um forte sentimento de perda entre os xangôs de Água Fria e redondeza, nesta "subárea do Recife inconfundivelmente africanoide, proletária e plebeia”, no seu dizer (FREYRE, 1979, p. 29). ${ }^{22}$

Pai Adão faleceu pouco antes do advento do regime político do Estado Novo no Brasil (19371945), num quadro de instabilidade política e social às vésperas da Segunda Guerra Mundial. Não chegou a assistir o drama vivido pelos filhos de santo frente ao período de maior repressão aos xangôs em Pernambuco durante a política autoritária e racista do interventor Agamenon Magalhães, que tratava os terreiros como covis de "bruxaria", de "doentes mentais" e de possíveis "comunistas". Neste contexto, a polícia humilhava os povos de santo, prendendo e confiscando pessoas e objetos-

\footnotetext{
${ }^{21}$ A edição de 27 de março de 1936, o Jornal Pequeno noticiou o falecimento de Pai Adão da seguinte maneira: "Com a avançada idade de 60 anos, faleceu hontem, em sua residência a Estrada Velha de Agua Fria, o Sr. Felippe Sabino da Costa, ou, simplesmente "Pai Adão", cognome este que lhe deixou famoso, entre os affeicionados do "Xangô" em Pernambuco. Bastante conhecido nas zonas que compreendem Olinda e Beberibe, "Pai Adão" conquistou, ha cerca de trinta anos, uma popularidade invulgar, dadas as sua atividades naquella seita. Com o seu fallecimento, hontem, em virtude de um ataque cardíaco, desfilaram diante do corpo inanimado, cerca de 500 pessoas, todas dominadas de profunda consternação. Com seu fallecimento, hontem, em virtude de um ataque cardíaco, desfilaram diante do corpo inanimado, cerca de 500 pessoas, todas dominadas de profunda consternação. Sabino Costa deixa numerosa prole, constituída de filhos, netos e bisnetos. Era casado com D. Maria da Hora da Costa [...]”. In: MORREU “PAE ADÃO”, O MAIS ANTIGO REPRESENTANTE DA SEITA AFRICANA NO RECIFE. Jornal do Pequeno, Recife, 27 de março de 1936.

22 "Espécie de evangelista de Adão" (BRANDÃO \& MOTTA, 2002), Gilberto Freyre soube da morte do amigo no Rio de Janeiro, e um mês após o ocorrido, escreveu uma crônica para o Diário de Pernambuco: Quando soube da morte de Pae Adão, lembrei-me que uma vez ele me disse: “o coração está velho, Gilberto”. O coração estava mais velho que o resto do corpo - aquelle corpo enorme de homem de quase sessenta anos que parecia o de um rapaz de vinte, quando danava até de madrugada as danzas de changô (FREYRE, 1936, p. 3).
} 
rituais. ${ }^{23}$ Quando dessas invasões policiais, Joana Baptista, que assumiu a liderança feminina do Sítio de Adão após a morte do babalorixá, escondia os orixás numa gameleira sagrada (iroko), quando não nos mocambos da vizinhança (CAMPOS, 1999). Conforme dito, Adão não presenciou estes eventos, faleceu pouco antes. Seu enterro talvez tenha sido o último grande ato público permitido ao seu povo, que aglomerou-se para celebrar o enterro do líder religioso, e, ao mesmo tempo, para reunir forças para tempos difíceis que se anunciavam.

Durante a cerimônia, a multidão aglomerou-se no Sítio para velar o corpo. O ato contou com a presença ilustre de Martiniano do Bonfim, chamado para realizar o axexê do amigo (CAMPOS, 2005). Da Catimbolândia, o corpo seguiu sua derradeira vereda, num cortejo fúnebre tomado de gente simples, intelectuais, artistas e autoridades políticas. Os relatos do velório e do enterro revelam os últimos testemunhos do carisma de Adão, conforme pode-se observar nas palavras de Fernandes:

A estrada velha de Beberibe então não cabia mais de gente. Ali, no Chapeu de Sol, em Água Fria, em Beberibe todo, era só no que se falava. Uma multidão densa se juntava, os olhos voltados para o morto. As orações subiam no ar, entrecortadas de soluços, os lábios tremiam as palavras em todos os filhos de terreiro. Como era querido o grande pai de terreiro! Sentiam a sua morte os que conheciam e o estimavam, os quais viveram ao seu lado e os que o viam só de longe. Morto agora, o casarão do Chapéu do Sol estava todo cheio dos seus velhos amigos que lhe foram dizer adeus. Pai Adão estava morto no seu caixão negro iluminado de velas. Os grandes encantados não ouviam as suas invocações. Estava ali estendido sem vida, á espera da clemencia de Xangô. O caixão de veludo negro foi levado para a capela. Todo o dia resaram ao seu lado. Toda a noite resaram em volta dele. Lá fora do terreiro ouvia-se: 'Pai Adão era bom demais! Você vai ao enterro de pai Adão?' Todo mundo dizia que sim (FERNANDES, 1937, p. 152-153).

O "casarão do Chapéu do Sol” era, na verdade, a casa simples do terreiro situada num sítio esplêndido, próximo a uma estação de trem, com cacimba dedicada a Oxum, mocambos e árvores frondosas, como o já mencionado iroko (Figura 03), gameleira venerada como santo (FERNANDES, 1937). O corpo de Adão foi velado na capela conjugada ao peji, cujo nome homenageia a fundadora do terreiro, Capela de Inês, em arquitetura católica, repleta de imagens cristãs, onde até casamentos já foram realizados. ${ }^{24}$ Malgrado a ortodoxia de Adão, a prática sincrética buscava legitimar a casa perante às autoridades, construindo maior aceitação social e expansão do "mercado de almas", sobre

\footnotetext{
${ }^{23}$ Vide a exemplo a matéria do jornal Folha da Manhã, de 24 de fevereiro de 1938 sobre a invasão policial num terreiro do Recife: "Deante da visita inesperada da polícia, parou de comer, levantou-se e entregou os pontos. E ella próprio foi entregando a polícia uma variada collecção de objetos do culto: uma boneca preta com olhos de vidro e cabelos negros, uma grande figa encarnada [...] José Almeida foi intimado a comparecer á polícia, onde será identificado”. In: BRUXARIA! VASSOURA, CHIFRES DE BOI E AGUARDENTE. Folha da Manhã. Recife, 24 de fevereiro de 1938. p. 4. Edição das 16 horas.

${ }^{24}$ Segundo depoimento de Walfrido José da Silva, sobrinho de Pai Adão e ogã mais antigo do "Sítio", quem construiu a capela foi Inês Joaquina Costa: "Foi ela quem fez a capela, tudo isto quem fez foi ela. Isto aqui é uma capela particular de santos. De santos da igreja católica. Aqui não só adora os santos africanos não, aqui é exclusivamente para estes da capela. Na época em que eu era menino, tinha casamento...". Entrevista concedida em 15 de janeiro de 2010, quando Seu Walfrido tinha 95 anos de vida.
} 
o qual dependia a sobrevivência do xangô. A mesma capela onde Adão tirava orações no mês mariano serviu de abrigo para o seu sepultamento. Daí o corpo seguiu no cortejo fúnebre:

No dia seguinte foi sepultado o pai de santo. Cerca de duas mil pessoas enchiam a estrada. Foi dispensada a carreta porque todos queriam pegar no caixão. As filhas de santo, travestidas de baiana, com as cores dos seus santos só nos collares, blusas brancas cheia de rendas e turbantes de rendas, abriam duas alas. A irmandade do senhor dos Martyrios seguia à frente do cortejo, toda paramentada. De mão em mão chegou o enterro à Encruzilhada. Ali, deixam levar o caixão na carreta. Mas, já próximo ao Campo Santo, ainda havia poeira na Estrada Velha de Beberibe... Calou o batuque do terreiro do Chapéu do Sol (FERNANDES, 1937, p. 153).

O cortejo sincrético foi acompanhado pela multidão, tomando a "Estrada Velha de Beberibe" (Estrada Velha de Água Fria) rumo ao largo da Encruzilhada, e, depois, ao Cemitério Público de Santo Amaro, última morada de Adão, e de tantos outros negros ali enterrados ao longo da escravidão. Durante o tráfico negreiro, o espaço das Salinas de Santo Amaro destinava-se à agência transatlântica, com os cativos recém chegados do continente africano ali permanecendo em estado de quarentena. Muitos não resistiam às moléstias e eram sepultados ali mesmo à toda sorte, outros morriam na travessia e eram arremessados ao mar (HALLEY, 2017). Não obstante a celebração fúnebre, Adão acabou tendo o mesmo destino de seus antepassados cativos, o antigo espaço de quarentena do tráfico negreiro, mesmo num contexto pós-1888.

Em vida passou maior tempo na Catimbolândia, no vale do Beberibe, contribuindo para organização deste território étnico e cultural privilegiado pelos povos negros desde o início da colonização. Em suas veredas, visitou outros lugares no Brasil (Salvador e Maceió) e na África (Lagos e região central do continente), estando sempre imerso num processo de "reafricanização" calcado em redes de relações assentadas na reconstrução de uma tradição nagô no Recife. Findou sua jornada numa outra "volta" a um chão africano recoberto por jazigos e mausoléus de famílias tradicionais e brancas da capital pernambucana, já próximo ao rio Beberibe em seu encontro com o Capibaribe. Fazendo jus aos adeptos das religiões dos orixás, onde tudo é volta, retorno à África, Adão realizou seu último regresso, mesmo a um Atlântico de distância. Foi esse seu derradeiro retorno à terra dos ancestrais. Terra do senhor, a bem da verdade, mas de memória e restos mortais africanos.

"Viveu como um grande místico. Amou seus filhos, e morreu cercado de verbenas e violetas" (FERNANDES, 1937). “O povo do Recife sentiu que desaparecia o seu grande babalorixá; que ce sumia a ultima voz verdadei-mente africana dos xangôs do Norte" (FREYRE, 1936). Pela religiosidade, Pai Adão conseguiu uma visibilidade então negada aos filhos de santo, debatendo o xangô a partir dos saberes da África. Quando não, soube praticar um sincretismo afro-católico, como forma de maior aceitação social e ganho econômico. Mostrava-se como um homem gregário, devotado à sua comunidade, mas também era um nômade, com viagens pelo Nordeste e pelo outro continente - o africano. A realidade do mundo ensinou a Adão a fazer uso de diferentes estratégias 
territoriais ao longo da vida, a partir das circunstâncias históricas, dos espaços geográficos e dos outros grupos com os quais cruzou para além do seu "Sítio", seja na Catimbolândia, seja em Salvador, Maceió ou em Lagos, nos seus diversos territórios transatlânticos.

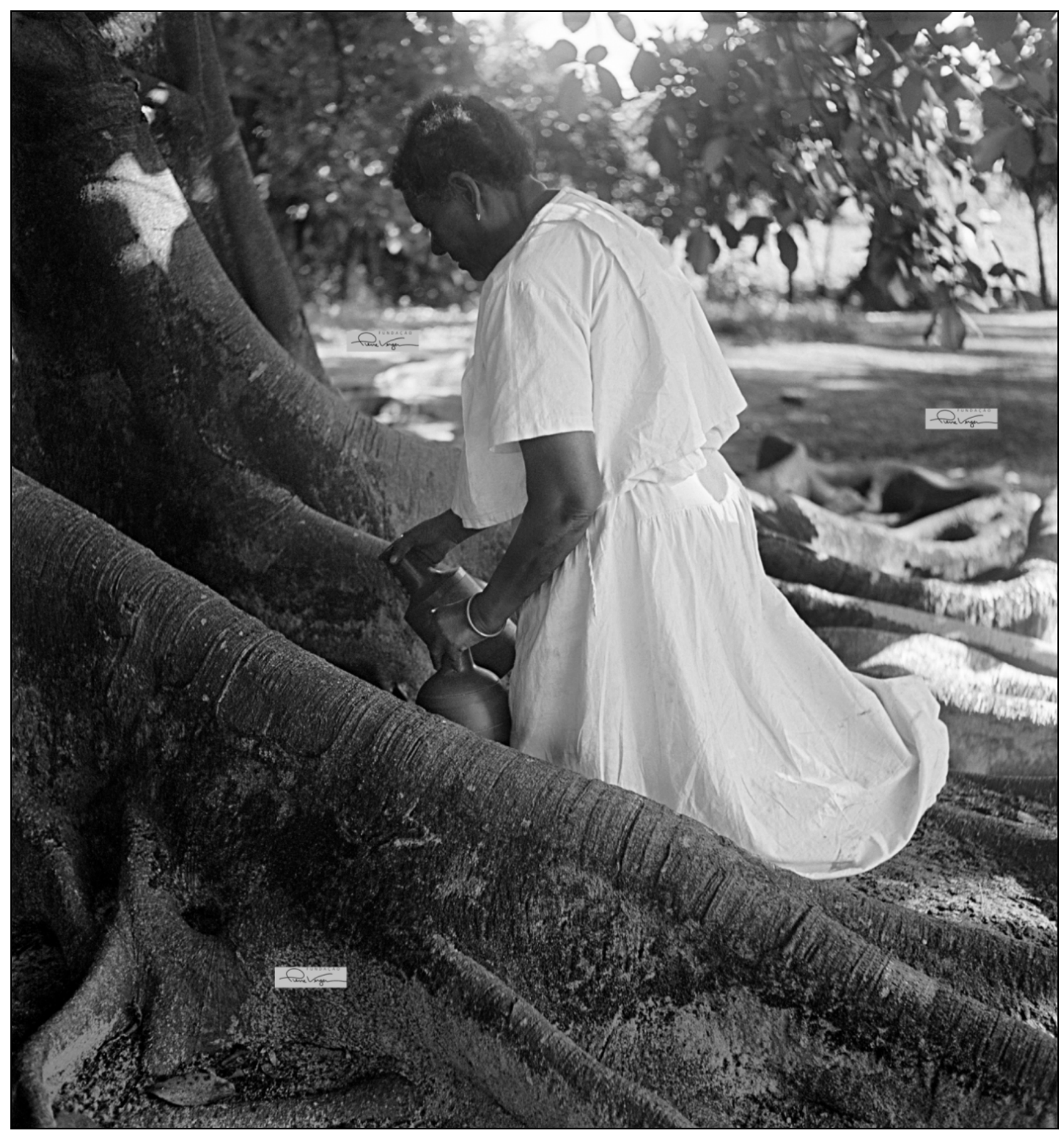

Figura 03: Mãe Joana Baptista venerando o Iroko, em 1947, Sítio de Pai Adão. Na imagem, observa-se a mãe de terreiro vestida de branco a realizar suas oferendas ao pé da árvore, a mesma onde ela escondia os orixás da casa quando das invasões da polícia durante a repressão do Estado Novo. Foto Pierre Verger. Xango Joana, Recife, Brasil (1947) - marca d'água exigida.

Fonte: Foto Pierre Verger@Fundação Pierre Verger. Tombo 35916.

Após a morte de Adão, seu filho José Romão assumiu a chefia do terreiro, e Joana Bode, sucessora legítima de Inês, a liderança feminina. Malaquias, também filho de Adão, assumiu o terreiro 
após a morte de Romão, em 1971, liderando a casa até 1984. Atualmente, com mais de trinta anos de liderança, Manuel do Nascimento Costa ("Manuel Papai”), coordena as atividades do Sítio. O nome do seu avô Adão permanece na linguagem corrente de iniciados e de leigos, afora pesquisadores. " $\mathrm{E}$ é largamente em seu nome que, até o dia de hoje, o xangô em Pernambuco procura legitimar-se" (BRANDÃO \& MOTTA, 2002, p. 52).

O reavivamento de sua memória ocorre entre seus filhos de santo, que reivindicam através de sua imagem, e, em segundo plano de Tia Inês, uma espécie de primazia sobre o campo religioso afropernambucano, respaldando-se inclusive no reconhecimento conferido pelas instâncias oficiais, que patrimonializaram o Sítio de Pai Adão em níveis estadual e nacional. ${ }^{25}$ A devoção à figura carismática de Adão trata-se de um mecanismo de preservação da memória coletiva da comunidade religiosa, que oficializa essa "presença de ausência” (CERTEAU, 2005) na própria toponímia do xangô. O terreiro Ilê Axé Obá Ogunté é mais conhecido como Sítio de Pai Adão, em detrimento ao seu nome oficial, que embora se volte à origem iorubá, acaba sobrepujado pela memória do seu antigo babalorixá.

Através deste legado, das histórias de luta e de suas identidades territoriais, os filhos de santo de Adão continuam a assegurar seu território de moradia, lazer e culto, transmitindo seus saberes e resistindo contra os inimigos da crença, sobretudo no atual cenário político brasileiro, marcado por um repúdio aos povos de matriz africana. Recentemente, em novembro de 2019, indivíduos contrários ao culto atearam fogo numa gameleira sagrada do Sítio de Pai Adão, o iroko, onde Mãe Joana Batista realizava suas oferendas rituais e onde escondia os orixás da casa quando das invasões policiais, conforme já mencionado. A árvore centenária tombou, restando apenas o tronco tolhido pelo fogo. ${ }^{26}$ Contudo, as práticas religiosas em torno do "pau encantado" permaneceram, como também outras territorialidades físico-simbólicas, dentro e fora do terreiro. O povo de Adão faz jus, assim, ao poema antirracista de Solano Trindade (2008), que faz referência ao OLORUM EKÊ, ao "POVO DE SANTO FORTE", que resistiu aos opressores do passado e que continuará resistindo aos do presente!

\section{REFERÊNCIAS}

\section{Livros, artigos, dissertações e teses}

ABREU, Maurício de. Sobre a memória das cidades. Revista da Faculdade de Letras - Geografia. Porto, série 1, vol. 14, 1998, p. 77-97.

ANJOS, Rafael Sanzio Araújo dos. Territorialidades quilombola: fotos \& mapas. Brasília: Mapas Editora \& Consultoria, 2011.

\footnotetext{
${ }^{25}$ O Sítio de Pai Adão foi tombado pelo Conselho Estadual de Cultura de Pernambuco pela Resolução N $05 / 85$, de 14 de agosto de 1985, assinado por Gilberto de Mello Freyre, presidente do conselho. Recentemente, em 20 de setembro de 2018, o Sítio de $4.190 \mathrm{~m}^{2}$ foi reconhecido como Patrimônio Cultural do Brasil pelo conselho consultivo do Instituto do Patrimônio, Histórico e Artístico Nacional - IPHAN no Processo N 1585-T-09.

${ }^{26}$ Vide matéria divulgada no portal do IPHAN, em 11 de janeiro de 2020: http://portal.iphan.gov.br/pe/noticias/detalhes/4 961/iroko-arvore-sagrada-do-sitio-de-pai-adao-cai-em-recife-pe Acesso em 15 de fevereiro de 2020.
} 
ARAÚJO, Rita de Cássia Barbosa de. As praias e os dias: história social das praias do Recife e de Olinda. Recife: Fundação de Cultura Cidade do Recife, 2007.

BASTIDE, Roger. Imagens do Nordeste místico em branco e preto. Rio de Janeiro: O Cruzeiro, 1946.

BONNENMAISON, Joel. Viagem em torno do território. In: CORRÊA, Roberto Lobato; ROSENDAHL, Zeny (Orgs.). Geografia cultural - uma antologia. Rio de Janeiro: EDUERJ, 2012, p. 279-304.

BRANDÃO, Maria do Carmo; MOTTA, Roberto. Adão e Badia: carisma e tradição no Xangô de Pernambuco. In: SILVA, Vagner Gonçalves da (Org). Caminhos da alma: memória afrobrasileira. São Paulo: Summus, 2002.

Xangôs tradicionais e umbandizados do Recife: organização econômica. Tese (Doutorado em História) - Faculdade de Filosofia, Letras e Ciências Humana - USP. São Paulo, 1986.

CAVALCANTI, P. As seitas africanas do Recife. In: Estudos Afro-Brasileiros. Recife: FUNDAJ, Editora Massangana, 1988. (Fac-símile de: Rio de Janeiro: Ariel, 1935). p. 243-257.

CAMPOS, Zuleica. Memórias etnográficas do Sítio de Pai Adão. Revista de Teologia e Ciências da Religião. Recife, v. 4, ed. 4, 2005, pp. 9-34.

O combate ao catimbó: práticas repressivas às religiões afro-umbandistas nos anos trinta e quarenta. Tese (Doutorado em História) - Universidade Federal de Pernambuco, Recife, 2001.

"Perseguida por Agamenon Magalhães: marcas de memória de uma mãe-de-santo pernambucana”. In: Revista SymposiuM. Ano 3, Número Especial, dez. 1999, p. 65-70.

CARVALHO, José Jorge de. Ritual and musico of the Sango cults of Recife, Brazil. Dissertação (Phd Departamento de Antropologia Social), The Queens University of Belfast, 1984.

CERTEAU, Michel De. A invenção do cotidiano - artes de fazer. Rio de Janeiro: Ed. Vozes, 2005. COSTA, Valéria Gomes. Trajetórias negras - os libertos da Costa d'África no Recife (18461890). Tese (Doutorado em História) - Faculdade de Filosofia e Ciências Humanas, Universidade Federal da Bahia, Salvador, 2013.

. É do Dendê! História e memórias urbanas da Nação Xambá no Recife (1950-1992). São Paulo: Annablume, 2009.

. Fluxo e refluxo: africanos e crioulos pós-1888 nas religiões afrodescendentes entre

Recife e Maceió. In: Anais eletrônico. Rio de Janeiro: XIII Encontro de História da ANPUH, 2008. p. 1-7.

FERNANDES, Albino Gonçalves. Xangôs do Nordeste: investigações sobre os cultos negrofetichistas do Recife. Rio de Janeiro: Civilização Brasileira, 1937.

FREYRE, Gilberto. Sobrados e mucambos. $1^{\circ}$ ed. digital. São Paulo: Global Editora, 2013 ( $1^{\circ}$ ed. impressa, 1936).

. Pai Adão, babalorixá ortodoxo. In: . Pessoas, coisas \& animais. São Paulo: Círculo do Livro, 1979, p. 29-30.

Guia prático, histórico e sentimental da cidade do Recife. Rio de Janeiro: José Olympio Editôra, 1968.

GUERRA, Lúcia Helena Barbosa. Xangô rezado baixo. Xambá tocando alto: a reprodução da tradição religiosa através da música. Dissertação (Mestrado em História) - Centro de Filosofia e Ciências Humanas, Universidade Federal de Pernambuco, Recife, 2010. 
HAESBAERT, Rogério. Território e multiterritorialidade - um debate. Revista Geographia, Rio de Janeiro, vol. 9, n. 17, p. 19-46, 2007.

HALBAWACHS, Maurice. A memória coletiva. São Paulo: Centauro, 2006.

HALLEY, Bruno Maia. Catimbolândia: tramas negras do xangô na Veneza Americana - os arredores do rio Beberibe (Recife, 1867-1945). Tese (Doutorado em Geografia) - Instituto de Geociências, Universidade Federal Fluminense, 2017.

HOBSBAWN, Eric; RANGER, Terence (Org.). A invenção das tradições. São Paulo: Paz e Terra, 2002.

LIMA, Vicente. Xangôs. Recife: Empresa do Jornal do Commércio, 1937.

LINS, Anilson José Bezerra. A relação e influência dos pesquisadores nos xangôs do Recife. Monografia (Bacharelado em Ciências Sociais) - Centro de Filosofia e Ciências Humanas, Universidade Federal de Pernambuco, Recife, 1992.

LOPES, Nei. Enciclopédia brasileira da diáspora africana. São Paulo: Selo Negro Edições, 2004, pp. 30-31.

MELLO, José Antônio Gonsalves de. "Uma reedição necessária" - apresentação dos Anais do $1^{\mathrm{a}}$ Congresso Afro-brasileiro. In: Estudos Afro-Brasileiros. Recife: FUNDAJ, Editora Massangana, 1988. (Fac-símile de: Rio de Janeiro: Ariel, 1935).

MOURA, Roberto. Tia Ciata e a Pequena África. 2 ed. Rio de Janeiro: Secretaria Municipal de Cultura, 1995 (Coleção Biblioteca Carioca).

NASCIMENTO, Luiz Cláudio. Bitedô - onde moram os nagôs: redes de sociabilidades africanas na formação do candomblé jêje-nagô no Recôncavo Baiano. Rio de Janeiro: CEAP, 2010.

ORTIZ, Fernando. Contrapunteo cubano del tabaco y el azúcar. Havana: ed. Ciencias Sociales, 1991.

PEREIRA, Zuleica Dantas. O Terreiro Obá Ogunté: parentesco, sucessão e poder. Dissertação (Mestrado em Antropologia) - Centro de Filosofia e Ciências Humanas, Universidade Federal de Pernambuco, Recife, 1994.

PIERSON, Donald. Negroes in Brazil: a study of race contact at Bahia. Chicago, III: University of Chicago Press, 1942.

POLLACK, Michael. Memória e identidade social. Estudos Históricos, Rio de Janeiro, v. 5, n. 10, 1992, pp. 200-212.

PORTO-GONÇALVES, Carlos Walter. A invenção de novas geografias: a natureza e o homem em novos paradigmas. In: SANTOS, M. et al. Território, territórios - ensaios sobre o ordenamento territorial. 2 ed. Rio de Janeiro: DP\&A, 2006.

RIBEIRO, René. Pai Rosendo faz uma ialorixá. O Cruzeiro, Rio de Janeiro, nov., 1949, p. 51-63.

SETTE, Mário. Maxambombas e maracatus. Recife: Edições Cultura Brasileira, 1938.

SOIHET, Rachel. A subversão pelo riso. Rio de Janeiro: FGV, 1998.

TRINDADE, Solano. Poemas antológicos de Solano Trindade. São Paulo: Editora Nova Alexandria, 2008.

\section{Fontes manuscritas}

Anotações de René Ribeiro, 1954 [Dudu].

Petição da Senhorinha Germana do Espírito Santo à Câmara Municipal de Olinda, s/d. 


\section{Boletins e Revistas}

ARQUIVOS da Assistência a Psicopatas de Pernambuco, 1935, p. 88.

O Espiritismo no Recife. Boletim de Higiene Mental. Recife, ano 2, n. 2, fevereiro de 1934, p. 04.

\section{Documentos oficiais}

CONSELHO ESTADUAL DE CULTURA DE PERNAMBUCO/FUNDARPE. Resolução N 05/85, de 14 de agosto de 1985. Tombamento do Terreiro Obá Ogunté.

IPHAN. Processo N 1585-T-09. Terreiro Ilê Obá Ogunté. Rio de Janeiro: Arquivo Central do IPHAN/Seção Rio de Janeiro.

\section{Jornais}

A “MACUMBA” A SERVIÇO DO FUTEBOL. Folha da Manhã, Recife, 31 de julho. 1944, p. 4. Edição Matutina.

BRUXARIA! VASSOURA, CHIFRES DE BOI E AGUARDENTE. Folha da Manhã. Recife, 24 de fevereiro de 1938. p. 4. Edição das 16 horas.

FECHADOS PELA POLÍCIA VÁRIOS XANGÔS. Diário de Pernambuco, Recife, 13 de fev. 1938, p. 7.

FREYRE, Gilberto. Pae Adão. Diário de Pernambuco: Recife, 28 abr. 1936, p. 3.

MORREU “PAE ADÃO”, O MAIS ANTIGO REPRESENTANTE DA SEITA AFRICANA NO RECIFE. Jornal do Pequeno, Recife, 27 de março de 1936.

UM ESPÍRITO RUIM NO CORPO DO CATIMBOZEIRO PEREIRA. Folha da Manhã. Recife. 21 mar. 1938. p. 1. Edição das 16 horas.

VAI SER RESTRINGIDA A LICENÇA PARA OS TOQUES NOS XANGÔS A POLÍCIA

BAIXARÁ UMA PORTARIA A RESPEITO. Diário de Pernambuco, Recife, 23 de julho. 1935.

\section{Matéria em site de pesquisa}

IROKO, árvore sagrada do Sítio de Pai Adão, cai em Recife (PE). Instituto do Patrimônio

Histórico Artístico Nacional - IPHAN, 11 de janeiro de 2019. Disponível em: http://portal.iphan.g ov.br/pe/noticias/detalhes/4961/iroko-arvore-sagrada-do-sitio-de-pai-adao-cai-em-recife-pe Acesso em 15 de fevereiro de 2020.

\section{Plantas}

Planta da Cidade do Recife e seus Arredores de 1876.

Planta do Departamento de Saúde e Assistência Médica do Recife de 1924.

\section{Entrevistas}

Walfrido José da Silva, ogan do Terreiro Ilê Axé Obá Ogunté (Sítio de Pai Adão). Entrevista concedida em 15 de janeiro de 2010. 